\title{
Teaching with graduate instructors Tips for a successful partnership
}

M any librarians, especially those involved with reference and instruction, collaborate with instructors to teach information literacy. Sometimes those instructors are faculty members, and sometimes they are graduate students who get tuition and/or a stipend (usually not much) to teach classes while they publish a thesis, integrate themselves into an academic setting, and try not to go too deeply into debt. Often times, they teach general courses like first- and secondyear composition or other introductory classes. Understanding how to work with these new instructors is rewarding and, most importantly, can help us provide meaningful library instruction as we more fully integrate ourselves into the classroom.

I have been fortunate to see the benefits of the graduate instructor/librarian partnership from both sides. I now work as reference and instruction librarian at the same institution where I was paired with my first librarian while I was teaching English as a graduate instructor. I currently partner with seven or eight graduate instructors each semester to integrate the library into their courses. Working with them reminds me of the difficulty of their position; they often have little or no experience teaching at the collegiate level and have the difficult task of establishing credibility and authority with students who are generally only a few years younger than themselves.

I can by no means speak to the experience of every graduate instructor or to every librarian who has worked with them, but I have learned a few things from seeing li- brary instruction from a graduate instructor's perspective and now from my perspective as a librarian.

1. Trust them. Graduate instructors know their students better than you do. And their students generally trust them already.

2. Befriend them. You don't have to hang out together on the weekend, but get to know their research interests. Find out if they have any research needs you could help them with, the same way you would with faculty. It sounds basic, but it's likely they don't see themselves as a researcher yet, and they'll appreciate you doing so.

3. Tell them about their victories. When a student is excited about his or her topic, give the credit to the instructor. Let the instructor know that a student was excited about the assignment or mentioned they liked the class.

4. Ask for really specific instructions. For example, are there any students with special needs in the classroom that you might need to know about? What is the instructor's general style of communication? For example, I taught a brainstorming session with a class that seemed unusually unparticipatory and I found myself floundering. Later, I watched the instructor teach and realized that he used a very different method—calling on students after each question. They had learned to interact in the classroom this way, and I had unwittingly veered the students away

Kacy Lundstrom is reference and instruction librarian.at Utah State University, e-mail: kacy.lundstrom@usu.edu ๑ 2011 Kacy Lundstrom 
from their familiar method. Had I known, I could have been more specific about my own teaching style and my expectations for student discussion.

5. Solicit feedback. Many graduate instructors will say "it was great/fine" though they may not mean it. How do you get them to tell you the truth? Ask for specifics, such as, Did I talk for too long? Was my approach to teaching what you were looking for? Do you think your students were engaged? What can I improve next time? What would you like me to do differently?

For example, I showed some first-year students a database that I later heard the instructor tell her students she didn't like, something I didn't know after meeting with her class multiple times. If I had asked for more specific feedback, I might have been able to discover this and discuss our differing opinions and discover the best strategies for helping her students find what they needed to know. Unless you ask for feedback, especially the critical kind, many graduate instructors may not want to bother you, or may not feel it is their place to be critical. Again, if you've established a strong rapport, this step is much easier.

6. Be a good resource for their students. More than anything, I appreciated the librarian's help as a graduate instructor. Some instructors may want to do it on their own, but with graduate teaching assignments and a hefty course load, I was grateful for any help I got.

7. If they give you time limitations, follow them. Especially in my first semester as a graduate instructor, I over prepared and planned everything to a $\mathrm{T}$. I often crammed a lot into sessions and became frazzled if I got off course. If you say you're going to take five minutes, take only five unless they give you a clear okay to keep going.

8. Ultimately, it's their class. Sometimes, I disagree with an activity, assignment, or teaching approach I see from graduate instructors. Perhaps I notice it more with graduate instructors because I am familiar with teaching English and have a concept of "the way I would do it," which is not the case with higher-level courses I partner with. Even in those instances that I disagree, I try to support the teacher. I simply refer them to the instructor, follow the guidelines the instructor has given me, and remind the student that their instructor has the final word on decisions relating to their assignments.

Sometimes my previous experience makes me more sympathetic to the behaviors of new graduate instructors teaching composition, and sometimes I find myself thinking, "I would never give my students that assignment or why isn't she...etc..." But I am always reminded that ingenuity and enthusiasm go a really long way, even when you don't yet have decades of subject matter knowledge tucked under your belt.

Obviously, a lot of these suggestions apply to any instructor/librarian partnership. I think one of the major differences is how willing so many graduate instructors are to co-teach with a librarian. They are open to suggestions and often eager to try new things. Many graduate students have been more than willing to open their classrooms to participation in research studies and to pilot new information literacy approaches. Librarians should recognize the unique position graduate instructors hold at our institutions, and the unique opportunity they offer librarians to work with them in providing quality instruction to students. $\boldsymbol{n}$

("Collaboration in the cloud..." continued from page 458)

8. Jason Kincaid, "Dropbox Security Bug Made Passwords Optional For Four Hours. TechCrunch," June 20, 2011, techcrunch. com/2011/06/20/dropbox-security-bug-madepasswords-optional-for-four-hours/.

9. Jason Kincaid, "Dropbox Breach: Fewer Than 100 Accounts Affected, But One Person Actively Exploited Security Hole," TechCrunch, June 24, 2011, techcrunch.com/2011/06/24/ dropbox-breach-fewer-than-100-accountsaffected-but-one-person-actively-exploitedit/. $n$ 